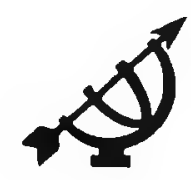

\title{
Die donker kant van die Verligting
}

\author{
L.F. Schulze \\ Skool vir Kerkwetenskappe \\ Potchefstroomse Universiteit vir $\mathrm{CHO}$ \\ POTCHEFSTROOM
}

\author{
Ek glo in God die Vader ... \\ Apostolicum \\ Ek glo in U, ek glo in $\mathrm{U}, \mathrm{o}$ God \\ Voltaire
}

\begin{abstract}
The dark side of the Enlightenment

The complex concept "Enlightenment" was ambiguous, even in the time of its inception in the I8th century. As such, it was ambivalent, revealing a dialectical tension between rational-irrational, and Christian-antichristian. The sunny face of the Age of Reason is well known: its rational, scientific, and "Christian" side. Its other side - dark, irrational, and antichristian - is less often explicated While mentioning aspects of its irrationalism, its antichristian character forms the focal point of this article. The Enlightenment was "Christian" in the sense of formulating Christian truth simply a little more "rationally"; yet "antichristian" in the sense of trading in Christianity for classical culture. Voltaire is called as a witness to this tension, and especially to the antichristian nature of this epoch. Since the rise of the Enlightenment Protestant churches in particular have displayed a disturbing openness towards this movement, embracing its (essentially antichristian) scientific ideals to promote Christian truth. The results of this impossible synthesis are seen, among others. in the tension between theological lecture room (reason) and pulpit (faith), and in the Western churches' (often) uncertain witness to Biblical truth. The dead end in which the mainstream liberal Enlightenment theology finds itself, is illustrated by the contradictory statements of theologians during the past four decades about angels - statements which incurred the contempt of natural scientists like Tipler, Weinberg and Feynman. To see the dark side of the Enlightenment is a challenge to believers (including theologians) to reconsider their allegiance to its scientific ideals and to rethink their position as witnesses to the truth, which is in Christ.
\end{abstract}




\section{Inleiding}

Die begrip Verligting was reeds in die agtiende eeu meersinnig en het vandag, na byna drie honderd jaar, heeltemal vervaag (Piepmeier, 1979:580; Brinton, 1972: 520-522; Schalk, 1971:620-621). Tog leef die Westerse wêreld met sy kultuur en godsdiens nog steeds in die skadu van die Verligting. Dit is 'n skadu wat die Westerse religiositeit vervlak en die getuienis van die Westerse kerk(e) in lewenswandel, prediking en teologie tot 'n mate verdof. Hierdie stelling geld in besonder van die Protestantse kerke, wat van die staanspoor af meer oop teenoor die Verligting was as die Rooms-Katolieke Kerk (Schmidt, 1979:601; Brumfitt, 1972:14).

Hierdie openheid duur tot vandag toe voort. Tiperend hiervan is 'n resente artikel van Hans Scholl, dosent aan die Kirchliche Hochschule, Wuppertal, wat in Calvin's Books (1997), die Festschrift vir Peter de Klerk van Calvin College, verskyn het. In sy artikel, "Von der Reformation zur Revolution. Die beiden Genfer J. Calvin und J.J. Rousseau vor der Frage nach sozialer Gerechtigkeit" (Scholl, 1997:235-256) betoog hy dat die sosiale geregtigheid wat Calvyn uitgestippel het, in werklikheid eers in dié van Rousseau geblom het. Sy vergelyking van Reformasie en Rewolusie dra dan ook as eerste onderopskrif: "Das sozialethische Plus der Revolution - Rousseau vor Calvin" (1997:249) - 'n opskrif wat veelseggend is. Getrou aan hierdie opskrif betoog hy dat daar by die Reformasie (in besonder by Calvyn) slegs ontluikende potensiaal teenwoordig was, wat eers in die sosiaal-etiese beskouings van die Verligting (i.c. Rousseau) ten volle ontluik het. Scholl is een van die Duitsers wat in besonder Calvyn en die Switserse Reformasie navors. Sy empatie lê by die Reformasie. Om Rousseau egter as die "voltooier" van Calvyn se werk en opvattings te sien toon duidelik die suigkrag van die Verligting op Scholl. Boonop hou sy opvatting die onontwykbare implikasie in dat die Reformasie in beginsel reeds rewolusionêr was - 'n implikasie wat deur Marxistiese historiograwe as feit opgedis is: die Reformasie was 'n "vroeg-burgerlike rewolusie" (Schulze, 1985:4-6). Scholl verteenwoordig die (tans nog) gangbare Protestantse openheid teenoor die Verligting met sy besondere visie op die Reformasie. (Die Verligting se tanende glans, soos afgeëts in die eksistensialisme, New Age en postmodernisme van ons eeu, lê buite die bestek van hierdie artikel.)

In die lig van bogenoemde kan dit vir ons as Protestante sinvol wees om 'n vlugtige terugblik op die Verligting te werp en opnuut ons eie posisie in oënskou te neem. Hierdie posisionering geskied (uiteraard taamlik sketsmatig en ongenuanseerd) in die lig van die ontwikkeling van die hoofstroom van die Protestantisme, wat inhou dat die reaksie van enkele agtiende-eeuse teoloë en negentiende-eeuse kerklike afskeidings op die Verligting nie ter sprake kom nie 


\section{Die komplekse en ambivalente aard van die Verligting}

'n Terugblik op die Verligting toon 'n komplekse verskynsel. Aan die een kant was die Verligting 'n kulturele epog met sy karakteristieke lewensgevoel en oorheersende lewensbeskouing. Aan die ander kant was dit 'n beweging, gelei deur eminente letterkundiges en filosowe, met 'n (verskillend geïnterpreteerde) program. Dit was eklekties en krities, en het die vooruitgang van die menslike geslag in sy geskiedenisfilosofie besing (vgl. Piepmeier, 1979:580-581; oor die kritiese instelling, Schalk, 1971:622-623). Die veelkantigheid en meersinnigheid kan geillustreer word deur twee omskrywings van die Verligting. "Die Maxime jederzeit selbst zu denken, ist die Aufklärung", sê Kant (aangehaal deur Piepmeier, 1979:579). Die filantroop J.B. Basedow (1724-1790) en sy leerling C.G. Salzmann (1744-1811) definieer weer anders: “"Aufklärung' (war) jede Veranderung des Bewusstseins, die einen Fortschritt brachte" (aangehaal deur Schmidt, 1979:597).

Bogenoemde komplekse aard van die Verligting is oor die algemeen bekend en word daar gelaat. Dit is egter insiggewend om die aandag op die ambivalente eintlik paradoksale - aard van die Verligting te vestig. Die ambivalente aard van die Verligting kan uit verskillende hoeke gesien word. Daar is eerstens die ambivalensie tussen redelik en onredelik, wat nie net paradoksaal is nie maar as dialektiek tussen twee teenoorgestelde pole funksioneer (Klapwijk, 1976). Tweedens toon die Verligting die ambivalensie van die wolf in skaapsklere, naamlik tussen Christelik (net redelik gestel) en antichristelik. Meijer (1976:9) tipeer die Verligting se weergawe van die Christelike waarheid as "bijna Christelijk" en is een van die weinige skrywers wat, soos Brinton (1972:522), die aandag vestig op die Verligting se dikwels uitgesproke antichristelike karakter. ${ }^{1}$

1 Eerlikheidshalwe moet hier op 'n derde paradoks gewys word: die ontnugterende gaping tussen teorie en praktyk, tussen wat hartstogtelik as evangelie aan die wêreld verkondig is en die skokkende tcenspraak daarteen wat in die privaat lewe van baie van die beroemde leiers van die Verligting sigbaar is. Twee voorbeelde hiervan word met teësin en daarom in 'n voetnoot hier vermeld.

(1) Rousseau se roem benus grootliks op sy mooi teoriet oor die grootmaak en opvoeding van kinders. Die bekende historikus, Paul Johnson (1988:21), werp egter 'n blik op die karakter en optrede van die beroemde man en sê: "From what we know of his character, it is unlikely that Rousseau could ever have made a good father Even so, it comes as a sickening shock to discover what Rousseau did to his own children". Uit sy verhouding met Thérése Levasscur (sedert 1745 tot sy dood, met wie hy nooit wou trou nie) is daar vyf kinders gebore. Op bevel van Rousseau het die vroedvrou telkens die naamlose en identiteitslose bondeltjie by die Hopital des Enfants-trouvés gaan afgool Vanselfsprekend kon hy oor hierdie naamloses geen navraag doen nie, nog minder hulle besoek. Ondertussen vertcl die statistieke van hierdie vondelinginstellıng sy eie verhaal oor die (morele?) voonuitgang van die mondige wêreld van die Verligting In 1746 is meer as 3000 babas daar afgelaai, teen 1758 styg dit na 5082 en in 1772 was dit 8000 per jaar. Plaas teenoor Rousseau se hantering van sy eie kinders Robespierre se 
Omdat die eerste ambivalensie meer algemeen-lewensbeskoulik (o.a. ook filosofies) van aard is (Cassirer, 1955), en die kerk gevolglik meer indirek raak, word slegs kursories daarna verwys. Hierdie verwysing mag egter nie agterweë bly nie omdat dit die kerk tóg raak en boonop reeds wesenlike trekke van die Verligting sigbaar maak

Hierdie artikel vind sy knooppunt in die tweede ambivalensie: die Verligting in sy byna Christelike karakter, waaronder sy antichristelike karakter skuil. Dit raak die kerk en die teologie ten diepste en vra opnuut besinning oor ons godsdienstige erfenis. Dit spreek vanself dat die twee genoemde aspekte (of ambivalensies) saamloop, mekaar wedersyds beïnvloed en onderskeibaar is, maar nie geskei kan word nie. Ten slotte word iets gesê oor die modeme teologie se dilemma om Protestantse teologie en tegelykertyd Verligtingsteologie te wil wees.

\section{Die eerste ambivalensie: redelik en onredelik}

Die eerste ambivalensie, naamlik die dialektiek van redelik en onredelik, beheers die Westerse kultuur en denke tot vandag toe.

Die Verligting het aan die een kant die mondige indiwidu en sy waardigheid beklemtoon. "Die Aufklarung is die uittrede van die mens uit die onmondigheid, waarin hy deur eie skuld verkeer. Onmondigheid is die onmag om hom van sy verstand te bedien sonder leiding van 'n ander", sê Kant (aangehaal deur Popma, 1956:374; vgl. Cassirer, 1955:163). Die mondige mens moes "waag om te weet" (Kant) deur die natuur en geskiedenis rustig, objektief en krities na te vors. Dit was die één kant, die ordelike, redelike, vriendelike, helder kant van die Verligting.

Maar onder hierdie rustige fasade was daar 'n ander krag werksaam: 'n onredelike, fanatieke idealisme om die vryheid en gelykheid van almal te verwerklik deur 'n bloedige rewolusie (1789 - vgl. Lanson, 1966:178). Deur die rewolusie is duisende mondige, waardige mense - juis in naam van die rede! - afgemaai. Dit was die ánder kant, die irrasionele, onordelike, duister kant van dieselfde Verligting.

lofprysing: "Rousseau is the one man who, through the loftiness of his soul and the grandeur of his character, showed himself worthy of the role of teacher of mankind" (aangehaal deur Johnson, 1988:3), dan is dit duidelik dat die Verligting sy eie mite gefabriseer het.

(2) Voltaire was 'n kampvegter vir moraliteit, wat stewig gegrond was in sy deisme Tog het hy vir jare 'n corspelige verhouding met madame du Châtelet gehad en later selfs 'n bloedskandigc verhouding met sy suster se dogter (Gay, 1966:5-6) 
Dooyeweerd (1949:37) tipeer hierdie dialektiek as die moderne humanistiese grondmotief van natuur en vryheid en gee hieroor ' $n$ helder insig in die dilemma en gespletenheid van die moderne filosofie. Die probleem van die filosofie, sedert Kant tot vandag, was om die outonome mens met sy vryheid êrens in 'n wetmattge natuur ingepas te kry.

Om die probleem te illustreer word hier twee voorbeelde genoem. In die eerste geval, naamlik die van Sartre, loop die "lyn" tussen wetmatigheid en vryheid tussen al die dinge aan die een kant en die mens aan die ander kant. 'n Ding se bestaan is voltooi, afgerond soos 'n argiteksplan; dis definieerbaar. 'n Ding bestaan en-soi, dit wil sê in homself. Die mens daarenteen is in wording, vry en ondefinieerbaar. Hy bestaan pour-soi (vir homself) en vra na die wese van die dinge (Heyns, 1974:36). Die tweede voorbeeld, dié van Tipler in sy The physics of immortality (1995), is meer gekompliseer: die mens is, soos alles, deel van die fisiese, wetmatige werklikheid, wat op 'n bepaalde punt tog sy dialektiese teenpool in die metafisiese (God) en menslike wilsvryheid openbaar. Tipler is matematiese fisikus en kosmoloog wat hom met die eskatologie (d.i. die toekomstige ontwikkeling van die kosmos) besig hou. Hy reduseer die mens (soos Lamettrie) tot 'n masjien en beskou die menslike brein as 'n superkomper, onderworpe, soos alle dinge, aan die bekende fisiese wette (Tipler, 1995, preface, xi). Aan die ander kant wil hy met sy Omegapunt-teorie die bestaan van God, die wilsvryheid van die mens en sy onsterflikheid aantoon (Tipler, 1995:13).

Terwyl Sartre ons 'n ateistiese humanisme as filosofie aanbied, wil Tipler wetenskap en Christelike godsdiens versoen. Sy projek lyk vir die Christen meer belowend as dié van Sartre. Tog kom Tipler nie bo die gereduseerde "Christendom" van die Verligting uit nie maar bly vassteek in die "God, deug en onsterflikheid" van die Verligting. Daarby is hy eerlik genoeg om te erken dat die Christologie vir sy teorie probleme bied (Tipler, 1995:16). Dis 'n rare erkenning van 'n kroniese probleem vir elke vorm van Verligtingsdenke: wat gemaak met die steen wat die tempelbouers verwerp het? (Ps.118:22). Hierdie probleem word slegs genoem omdat dit tiperend van die Verligting is. Die beredenerng daarvan sentreer egter in die Christologie, wat buite die grense van hierdie artikel val.

Uit die hoek van die kunsgeskiedenis belig Meijer (1976:32-59) dieselfde dialektiek. Hy noem dit die "Januskop van de revolutie" (1976:37). Sy analise trek saam in die visuele kontras tussen twee skilderye van tydgenote, naamlik David se "Die dood van Marat" (1793) en Goya se "Sombere voorgevoelens" (1810). Om vergelyking te vergemaklik word die twee skilderye op opeenvolgende bladsye van die boek langs mekaar afgedruk (Meijer, 1976:44,45). David se skildery toon die skoon en skerp buitelyne van Marat en van die bad, waarin hy sit. Duidelike trekke van die gesig en 'n fisiologies korrekte tekening van die spiere van die een arm wat oor die rand van die bad hang, val op. In die hangende arm is daar nog 'n pen tussen die lewelose vingers. 'n Mens kan David 
Dle donker kant van die Verllgting

se skildery 'n natuurgetroue afbeelding noem. Goya se ets is alles behalwe natuurgetrou. Dit toon 'n knielende figuur wie se vingers, dele van sy kleed en hare vervloei in die onheilspellend donker agtergrond ('n parodie van Christus in Getsemané?). Meijer (1976:48-49) som die kontras soos volg op: "De revolutie heeft een Januskop. David toont ons het officiële gelaat, met de schijnbaar klassieke trekken. Goya laat de andere kant zien: een van pijn vertrokken gezicht, dat vertwyfeld aandoet. Goya is het tegenbeeld van David". David en Goya is ver-beelders van die onmiskenbare ambivalensie van die rasionele en die irrasionele van die Verligting (kyk ook Rookmaaker, 1970:50-58).

\section{Die tweede ambivalensie: byna Christelik en antichristelik}

\subsection{Die verhouding Reformasie-Verligting (rewolusie)}

Scholl se artikel, waarna in die inleiding verwys is, verteenwoordig die gangbare beskouing oor die verhouding van Reformasie en Verligting (met sy gepaardgaande rewolusie). Daarvolgens lê die een in die verlengde van die ander en het die stimulus wat van die Reformasie uitgegaan het, eintlik in die Rewolusie sy beslag gekry (kyk ook Cassirer, 1955:160-182).

Wie egter met eerlike oë na die geskiedenis kyk, kan hierdie gangbare opvatting nie aanvaar nie maar moet, soos Groen van Prinsterer, die antitese tussen Reformasie en Rewolusie raaksien. Die Reformasie was immers ' $n$ geweldige golf in die kultuurgeskiedenis van die Weste om die leer, diens en tug van die vroeë kerk in die sestiende eeu te herstel. In sy bekende traktaat, Die noodsaak van die reformasie van die kerk, beredeneer Calvyn dit uitvoerig dat die regte kennis (leer) en verering (diens) van God die fondament van die kerk is en deur die kerk met die nodige dissipline (tug) bewaar moet word (Calvyn, 1958:123-234). Die ware kennis en verering van God het ingrypende invloed op die onderwys gehad. In Duitsland dra Luther dit aan Melanchthon op om die skole te hervorm; in Straatsburg werk Sturm saam met Bucer aan dieselfde saak en in Genève rig Calvyn saam met die Raad die Akademie op. Onderwys is nou nie meer, soos in die Middeleeue, net opleiding van priesters nie. Dit word opleiding van almal vir alle fasette van die lewe (Parker, 1977:150; Moore, 1984:142,147; Van der Walt, 1984). Ook die ekonomiese lewe word met Bybelse lig verhelder. Hierin het Calvyn, die eksegeet, die leeue-aandeel gehad. Hy het ingeroei teen die magtige stroom van die Middeleeuse tradisie, wat privaatbesit met argwaan bejeën het, rente as woekerwins beskou het en die onproduktiwiteit van geld verkondig het. Hierdie "Christelike" tradisie van die Middeleeue was egter van Griekse afkoms. Aristoteles het immers geleer dat gemeenskaplike besit en onproduktiwiteit van geld in die natuurreg geanker is. Daarteenoor stel Calvyn die soewereine toebedeling van God, wat geestelike en stoflike gawes na sy welbehae uitdeel. 
Dit hou in dat privaatbesit as sodanig nie sondig is nie - dit word in die agste gebod veronderstel. Hy verwerp ook die steriliteit van geld en sê dat geld teen 'n billike en regverdige koers vir produksiedoeleindes uitgeleen mag word (Esser, 1997; Schulze, 1985). Só is die hele lewe, as 'n lewe uit die geloof, onder die gesag van die Woord van God geplaas. In hierdie proses het die Reformasie sanerend op die maatskaplike lewe ingewerk. Op dit wat van die Renaissancehumanisme bruikbaar was, is beslag gelê (bv. onderwys en filologie) en in diens van die Koninkryk van God gestel (vgl. Wendel, 1971). Die humanisme van die sestiende eeu is deur die Reformasie grootliks gestuit en in Christelke bane gelei.

Twee honderd jaar later is dit so beskik dat die teenoorgestelde gebeur. Die sekulêre impulse van die sestiende-eeuse humanisme kry die oorhand en lei die Reformatoriese godsdiens in humanistiese, kwasigodsdienstige bane. In naam van die mondige mens word die gesag van die Woord geminag. Die gehoorsaamheid aan die Woord word ingeruil vir vryheid van spraak en denke, en die Woord self word aan die kritiese rede onderwerp. In die sintese met die humanisme word die Protestantse godsdiens die "godsdiens van vryheid" (Cassirer, 1955:160). Die verskillende toebedeling van God word ingeruil vir 'n gewaande gelykheid en die broederskap van die gelowiges (Joh. 20:17) word 'n broederskap van alle mense. "Alle Menschen werden Brüder", dig Schiller en toonset Beethoven. Dis bekend dat die "gelykheid" die koppe van die Franse koningshuis gekos het en dat die "broederskap" in 'n bloedbad ontaard het. Die Verligting met sy vryheid en gelykheid het verwoesting op die politieke en maatskaplike lewe gesaai. Wat ten slotte oorgebly het, was óf 'n blatante ateïsme, óf 'n deïstiese, "redelike" Christendom. Die Verligting was, in die woorde van Gay se 1967-publikasie niks anders nie as "The rise of modern paganism".

\subsection{Die Verligting: byna Christelik}

Hoe seer die Verligting 'n epog met sy eie lewensgevoel en lewensbeskouing was, wat ook die kerk en teologie gestempel het, blyk uit die geleidelike oorgang van Protestantse Reformatoriese teologie na Protestantse Verligtingsteologie. Dit is duidelik waar te neem in die Duitse state, en moontlik op sy duidelikste in Skotland. Baie van die Skotse leiers van die Verligting was prominente en invloedryke predikante, wat die nuwe idees aan hulle gemeentes oorgedra het idees wat oor die algemeen kritiekloos deur die gelowiges aanvaar is (Brumfitt, 1972:14)

In Frankryk was die Verligting as beweging baie sterker antikerklik gestempel. En tog sou 'n mens uit die werke van die Franse denkers van die agtiende eeu baie voorbeelde kon aanhaal wat die indruk skep dat die Verligting die Christelike waarheid omhels het - net meer redelik en wetenskaplik geformuleer. Die begin van die Twaalf Artikels en die bekende woorde van Voltaire is by wyse van 'n motto as voorbeeld hierbo aangehaal. Die woorde klink dieselfde, 
Die donker kant van die Verligting

behalwe dat 'n mens die indruk kry dat Voltaire se formulering meer emosioneel gelaai was en skynbaar van 'n dieper geloofsoortuiging as dié van die Apostolicum spreek!

Juis omdat die Verligting in Frankryk 'n sterker antikerklike profiel getoon het, kom die ambivalensie van byna Christelik (of redelik-Christelik) en antichristelik hier duidelik na vore. Gevolglik word na Voltaire verwys om die ambivalensie toe te lig - nie omdat hy die enigste voorbeeld sou wees nie, maar om die artikel binne perke te hou.

Voltaire wil die geloof (in sy terme) behou, maar dit duidelik teenoor die rede afgrens. Hy sê: "My sole task is to think in human terms. Theologians make divine decisions. That is something altogether different. Reason and faith are contrary by nature". Voorts verwys hy na Collins: "Reason does not prove either the immateriality or immortality of the soul; as a philosopher I doubt; as a Christian I believe" (aangehaal deur Lanson, 1966:62). Sulke uitsprake was waarskynlik veral gedra deur takties-politieke oorwegings; 'n poging om as vrydenker(s) te midde van die mag van die Roomse Kerk in Frankryk te oorleef deur die hande van die Inkwisisie te ontglip. Hoe dit ook al is, sulke geluide word die wêreld ingestuur sodat almal kan weet dat die Verligting nie teen die Christendom gekant is nie maar (skynbaar) volle rumte daarvoor laat. Trouens, die Engelse deïs Toland was een van die eerstes om met sy Christianity not mysterious (1696) hierdie geluide te laat hoor (Cassirer, 1955:171).

Voltaire glo dus in God. Vir die bestaan van God het hy genoegsame redelike bewyse, naamlik in die ordelike sisteem van die kosmos, wat 'n eerste Oorsaak vereis. Die bestaan van God vloei voort uit die wet van kousaliteit. "In the opinion that there is a God one finds certain difficulties, but in the contrary opinion there are absurdities", sê Voltaire (aangehaal deur Lanson, 1966:58-59). In sy latere lewe reduseer hy God nie meer tot eerste oorsaak nie maar lê klem op God as grondslag van daardie edelste vrug van die menslike rede: sedelike gedrag. God is die bron van deug (Lanson, 1966:149).

Meijer (1976:9) dui 'n dieper perskektief aan in die lig waarvan die "byna Christelike" karakter van die Verligting (rewolusie) gesien moet word: "Het ongeloof is als religie geordend en het is geordend naar het model van ... het geloof? Het ligt daarom in de aard van de revolutie, dat ze met de reformatie verward wordt".

Die Verliging met sy vriendelike, byna Christelike aard het nie net die Protestantse teologie oorrompel nie maar selfs sy stempel op die liturgie afgedruk, met name op die "onskuldige" kerksang. Die Nederlandse Gesangboek (1806) toon hiervan duidelike tekens, soos blyk uit die eerste helfte van Gesang 53 vers 1 : 
Mijn God! wat ooit in mij verdoov'

dat ik altijd aan U geloov'

aan deugd en eeuwig leven!

Dan zal 't gevoel van mijn waardij,

Hoe hobblig hier mijn pad ook zij,

Mijn' boezem nooit begeven.

In hierdie reels kry die Christelike geloof 'n paar kinkels. Eerstens word die ekumeniese belydenisse se "Ek glo in God" ingeruil vir 'n geloof aan God. Die verskil is ingrypend, omdat die volslae vertroue op God alleen ingeruil word vir 'n blote erkenning dat Hy bestaan. Tweedens is die bekende trits "God-deugonsterflikheid" prominent. Derdens is genoemde trits die onderbou van die humanistiese waardigheid van die mens.

\subsection{Die Verligting: antichristelik}

Wanneer die Verligting se masker van vriendelikheid en redelike Christelikheid afval, word sy ware antichristelike aard sigbaar (Brinton, 1972:521). Dit gebeur egter nie maklik dat die masker afval nie omdat die Verligting nie sy eie godsdienstige begrippe geformuleer het nie maar die kerk se woordeboek gebruik het (vgl. Meijer, 1976:9).

Voltaire bied ons egter tog 'n blik agter die masker. Hy bely entoesiasties sy geloof in God. Hy doen dit egter tydens 'n sonsopgang. Dit gee aan sy geloof 'n duidelike kleur van natuurmistiek. Bowendien het hy God nodig om die kousaliteit van die natuurorde te verklaar en om moraliteit te begrond. Dit wek die vermoede dat die God wat Voltaire verkondig, nie die God van die Bybel is nie.

Hierdie vermoede word bevestig deur die woorde waarmee Gay (1966:5) Voltaire se intense Bybelstudie tydens die jare 1734-1749 teken:

Painstakingly, with grave hostility and alert intelligence, Voltaire and madame Du Châtelet studied every verse of Holy Writ, using commentaries, higher criticism, deist propaganda, and their own secular common sense to single out the cruelty of the Chosen People, the inanity of the miracles related in the New Testament, the contradictions and incoherences that mark many of the books of the Old Testament.

'n Tweede aanhaling, hierdie keer uit Lanson se gesaghebbende studie oor Voltaire, teken Voltaire se opvatting nog nader:

Humanly speaking, the Bible is fascinating reading, like Homer; and Jesus is a rustic Socrates. But the time to adopt this point of view had not yet arrived. The first task was to destroy in men's minds the prejudiced notion of divinity, 
Die donker kant van die Verlligting

the habit of blind respect that gave the Bible and the New Testament a place apart among the monuments of the human spirit. This explains the reason for the form of Voltaire's attack, and the fact is that it proved effective (Lanson, 1966: 145-146; eie kursivenng). ${ }^{2}$

Voltaire was 'n verbete deïs, wat in sy later jare harder teen Holbach se ateïsme gestry het as teen die teoloë van die Sorbonne. Tog maak sy stryd teen die ateïsme hom nog nie Christelik nie. Inteendeel, juis Voltaire bied ons 'n blik agter die masker sodat ons die onoorbrugbare kloof tussen die redelike Verligtingsgodsdiens en die Bybelse godsdiens baie duidelik kan sien.

Die Verligting het nie die Christelike godsdiens net redelik geformuleer nie maar die Christelike geloof, wat leef by die openbaring van God in die Seun van sy liefde (Kol. 1:13) onverbiddelik en finaal onderstebo gekeer. Gay (1967:59-65) toon byvoorbeeld dokumentêr aan watter trauma die afswering van die Christendom by sommige leiers van die Verligting (bv. Lessing, Wieland en Hume) veroorsaak het, en dat die Verligting ten slotte die Christelike geloof vir die Klassieke Grieks-Romeinse kultuur ingeruil het.

In sy antichristelike aard bied die Verligting, ten spyte van sy optimistiese geskiedenisgeloof, geen progressie nie maar 'n regressie, 'n repristinasie van die Klassieke heidendom. Die antichristelike aard van die Verligting loop ten slotte saam met die irrasionele, die duistere, die onsinnige oortuiging dat die beste pad vorentoe die een terug is - terug, verby Jesus Christus tot by die GrieksRomeinse kultuur. Terloops moet opgemerk word dat die Neo-Marxiste van die Frankfurter Schule op 'n analoë wyse vanuit hulle eie raamwerk van 'n kritiese teorie die dialektiese progressiewe regressie van die Verligting onder oë bring. In navolging van Heidegger huldig hulle 'n grondige vervalteorie: die geskiedenis tot op hede toon 'n kontinue vooruitgang-in-verval. Wat verval, is die voortgaande realisering van menslike vryheid, wat juis deur die Verligting se vooruitgangsgeloof beloof is (Rohrmoser, 1970:39-43).

2 Voorbeelde van die antichristelike aard van die Verligting is daar in oorvloed, byvoorbeeld die sarkasme waarmee Diderot sy Pensées philosophiques begin: "I am wnting about God, and I reckon on having only a few readers" (aangehaal deur Brumfitt, 1972:120); of die byterigheld waarmee Voltaire in sy Lettres philosophiques die godsdiens in Engeland teken: die Episkopaalse sekte (brief 5), die Skotse presbiteriaanse sekte (brief 6) en die antitrinitariërs (brief 7), vir wie hy, na 'n snedige opmerking teen Athanasius, 'n lansie breek (Voltaire, 1986:55-64). 


\section{Die Verligting en die kerk}

\subsection{Regressie as omkering van die geloof}

By al die lig wat die Verligting gebring het, was die poging om die horlosie terug te draai nie oorspronklik nie. Lank tevore het koning Agab die resep reeds gegee. Hy het aan Giël, die argitek uit Bet-el, opdrag gegee om Jerigo, wat sedert die dae van Josua 'n ruïne was, as militêre vesting te herbou - iets wat Josua die volk laat sweer het om nie te doen nie (Jos. 6:26). Bowendien "herstel" Agab die Baäldiens in Palestina. Hy draai die klok omtrent 500 jaar terug - en dan lyk Palestina weer soos in die dae voor die intog: Jerigo is 'n versterkte stad en die diens van Baal is offisiële religie (1 Kon. 16:29-34). Die gedagte aan die genade van God, aan die gawe van die land (want dit is waarvan die ruines getuig het) moes uitgeroei word.

Dan kom die leiers van die Verligting en probeer die horlosie byna twee duisend jaar terugdraai - tot vóór die Christendom. Die wêreld moet weer lyk soos in die tyd voor Christus, 'n herlewing van die heidense Grieks-Romeinse beskawing. Die gedagte aan die genade van God, aan die onuitspreeklike gawe van sy Seun (2 Kor. 9:15), moes vervang word met 'n ánder, "redelike" geloof.

Albei was pogings, nie om die geloof in God te verwerp nie, maar om dit in sy teendeel om te keer (Meijer, 1976:9; vgl. Cassirer, 1955:135: “... not .. in its rejection of belief but rather in the new form of faith ..."). Dán sou alles skynbaar normaal kon voortgaan.

Die Verligting in sy redelike, vriendelike gelaat, stry immers nie teen die geloof nie maar teen die bygeloof. Bygeloof is egter volgens die nuwe definisie van die Verligting die ou "metafisiese" geloof in 'n Drie-enige God wat die wêreld bestier en lei. Om hierdie "bygeloof" af te breek stel Voltaire twee metodes voor, naamlik (1) die skeiding van geloof en rede (waarna reeds verwys is), en (2) die uitbreiding van die eksperimentele metode na die metafisika, sodat metafisika die voortrap van die fisika word (Lanson, 1966:63-67). Só word na die opvatting van die Griekse filosowe teruggekeer: teologie is mitologie, maar word ook deur Plato en Aristoteles as eerste filosofie of metafisika van die natuurfilosofie onderskei (Wentsel, 1981:26-27). Terselfdertyd word hiermee 'n ander samehangende wêreldbeskouing vanuit die ondermaanse gekonstrueer (vgl. Rolston, 1987:7, 297-300). Die omkering van die geloof vind geruisloos plaas.

\subsection{Het die kerk nog bestaansreg en teologie 'n taak?}

Die Verligting was ten diepste 'n religieuse beweging. Dit verkondig geloof en 'n samehangende wêreldbeskouing. Dit gebruik die woordeboek van die kerk en kom met dieselfde pretensie as die kerk. Het die kerk met sy prediking daarmee 
oorbodig geword? Johnson (1988:1-2) teken die oorweldigende impak van hierdie vraag in duidelike taal en word hier breedvoerig aangehaal:

With the decline of clerical power in the eighteenth century, a new kind of mentor emerged to fill the vacuum and capture the ear of society. The secular intellectual might be deist, sceptic or atheist. But he was just as ready as any pontiff or presbyter to tell mankind how to conduct its affairs. He proclaimed, from the start, a special devotion to the interests of humanity and an evangelical duty to advance them by his teaching. He brought to this selfappointed task a far more radical approach than his clerical predecessors ... For the first time in human history, and with growing confidence and audacity, men arose to assert that they could diagnose the ills of society and cure them with their own unaided intellects: more, that they could devise formulae whereby not merely the structure of society but the fundamental habits of human beings could be transformed for the better. Unlike their sacerdotal predecessors, they were not servants and interpreters of the gods but substitutes.

Teoloë praat so gemaklik oor "ons gereformeerde erfenis" of van "ons Protestantse tradisie". Die vriendelike, ordelike gelaat van die Verligting word raakgesien, en (mits ons "behoudend" is) torring ons so effens aan die gesag van die rede sodat dit nie meer heeltemal op die troon sit nie. Daarmee meen ons is die saak van die kerk en die teologie gered. Daar word immers "behoudend" op die Verligting voortgebou en die eensydighede daarvan word vermy.

Die meer progressiewe teoloë sien die vriendelike gelaat van die Verligting nie net raak nie, maar juis baie graag raak en begroet die Verligting as 'n era wat vir ons finaal wetenskap, tegniek en gevolglike vooruitgang gebring het. Die akonfessionele wetenskaplike, akademiese teologie bou die "redelike Christendom" van die Verligting na alle kante toe en met allerlei modelle uit, dis dikwels teorie as feit (waarheid) op, en vergroot só ons Bybelkennis en sorg vir die "vooruitgang" van die teologie.

Almal hou by Voltaire se metode om geloof en rede te skei: die een groep om daarmee die eie aard van die teologie te probeer red, die ander om juis die aard van die teologie vaartbelyn te maak - teologie moet ware wetenskap (d.i. geskoei op natuurwetenskap) word. Tipler (1995, preface, sin twee) stel sy standpunt onomwonde: "... that theology is a branch of physics". Laasgenoemde groep neem Voltaire se tweede stap dus ook ernstig, naamlik om die eksperimentele metode na die metafisika uit te brei.

Die poging om, soos die ander wetenskappe, wetenskaplike teologie streng krities-rasioneel te beoefen, beïndruk eienaardig genoeg nie die ander wetenskaplikes nie. Tipler (1995:xuii) sê byvoorbeeld: "I infer that the typical American theologian/religious studies professor has never seriously thought about the resurrection of the dead". Elders (1995:xxiii) erken hy openlik "... my very critical remarks directed against modern theologians". In 'n voetnoot (1995:340, 
noot 3) verwys Tipler na 'n ander prominente Amerikaanse natuurkundige, Steven Weinberg, met die woorde: "Weinberg is even harder on modem theologians than I am". Vervolgens haal hy Weinberg aan:

Religious liberals are in one sense even farther in spirit from scientists than are fundamentalists and other religious conservatives. At least the conservatives like the scientists tell you that they believe in what they believe in because it is true, rather than because it makes them good or happy. Many religious liberals today seem to think that different people can believe in different mutually exclusive things without any of them being wrong, as long as their beliefs 'work for them'... [W]e are surrounded by 'piety without content' ... I happen to think that the religious conservatives are wrong in what they believe, but at least they have not forgotten what it means really to believe in something. The religious liberals seem to me to be not even wrong (Weinberg, 1992:257-58 aangehaal deur Tipler, 1995).

Asof hierdie ooglopende degradering van die "wetenskaplike teologie" nog te hoog is, bring Tipler in dieselfde voetnoot die evalueringsyfer nog laer af deur direk na sy aanhaling van Weinberg te sê: "I have the same impression of liberal theologians. Feynman is even harder on liberal theologians than Weinberg. In his best-selling book Surely you're joking, Mr. Feynman! he calls them 'pompous fools"" (Feynman, 1986:259).

Die hoofstroom van die Westerse, "liberale" teologie het by die "redelike godsdiens" van die Verligting aangesluit. Dit wou, soos die Verligting, "modem" wees. Moderniteit was immers die sleutelwoord van die Verligting (Gay, 1967, passim; Rohrmoser, 1976:90). Met die rede word krttes gesif (Schalk, 1971:622623). Met die rede word ook logies verklaar. Só word in naam van die redelike godsdiens die histories-kritiese metode van die teologie gebore, waarmee die wonders van die Skrif uit natuurlike oorsake verklaar of andersins as fabels afgewys is (Lee, 1992). Om egter op die Verligting se redelike godsdiens voort te bou het meegebring dat die moderne teologie nog steeds in die ambivalensie van redelik en onredelik vasgevang is. Die ambivalensie word na vore gebring met die erkenning van geloof aan "mutually exclusive things" (Weinberg). Dit hou in dat paradoksale verklarings vir dieselfde verskynsel aangebied word. 'n Voorbeeld sal die saak toelig. In die jare vyftig het die teologiese ontmitologiseringsprogram aan ons kom leer dat die moderne wetenskaplik-tegniese vooruitgang die geloof aan die bestaan van 'n metafisiese wêreld (w.o. engele) onmoontlik maak. Laasgenoemde was verouder en agterhaal deur die progressiewe stroom van die geskiedenis. Mirabile dictu verskyn daar in 1998 in 'n dagblad 'n artikel onder die opskrif "Calling angel power" (Sboros, 1998), waarin presies die teenoorgestelde beweer word. Die onderopskrif sê dit reeds: "The more technological our societies become, the more interest grows in supernatural beings ..." Die interessante van die artikel is dat bekende teoloë daarin aan die woord kom. Om die paradoksale aard van die "verklaring" van die moderne teologie eksplisiet te 
Die donker kant van die Verligting

stel kan die argumente logies geformaliseer word: $\mathrm{A}=$ die moderne wetenskapliktegniese wêreld; $B=$ geloof aan (metafisiese) engele. Die moderne teologie verklaar die implikasie (aangedui met $>$ ) van A soos volg:

$$
\begin{aligned}
& \mathrm{A}>\text { nie-B (ontmitologisering) } \\
& \mathrm{A}>\mathrm{B} \text { ("angel power"). }
\end{aligned}
$$

Dit is dus geen wonder dat natuurwetenskaplikes die "wetenskaplikheid" van die moderne teoloë degradeer en dat die bestaansreg van kerk en teologie ons konfronteer nie. Immers, wanneer die teologie met 'n relatiwistiese geloof in "mutually exclusive things" (Weinberg) en met paradoksale verklarings van dieselfde gegewe die volk van God probeer voed, het dit sy eie taak opgehef en 'n bedreiging vir die kerk geword. Die paradoks sou natuurlik ook "postmodernisties" verklaar kan word as ewe geldige verklarings van dieselfde verskynsel uit verskillende gesigshoeke. Dit sou egter beteken dat die postmodernisme 'n blote verlengstuk van die modemisme is - iets wat nie alle postmoderniste vreugde sal verskaf nie (kyk bv. Rose, 1992:49-50). Met watter verklaring ook al, die inherente ambivalensie as 'n probleem vir die teologie bly onaangeraak. Omdat die lewensgevoel is Suid-Afrika nog oorheersend "modern" is, word nie verder op die postmodernisme hier ingegaan nie (vir 'n oorsig van literatuur oor postmodernisme, kyk Jencks, 1996:14-15).

\subsection{Slot}

Dit kan genesend op die moderne teologie inwerk om die ambivalente Verligting se donker kant onder die masker vir eens en vir altyd te bekyk en sy antichristelike karakter raak te sien. Dan sal die moderne teologie genees van die navolging van die ambivalente aard van die Verligting en bevry word van Voltaire se resep van die skeiding van geloof en rede wat (nie by Voltaire nie maar wel by die moderne teologie) ontaard het in 'n dialektiek - die dialektiek van kansel en kateder. Dit sal beteken dat die teologie weer sy vertrekpunt in die Bybelse openbaring sal neem en daardeur 'n "heel" vertrekpunt én lewensvisie sal bekom. So 'n koherente wetenskaplike vertrekpunt en genormeerde lewensvisie sal vir die opkomende postmodemisme 'n struikelblok word. Die kerk as volk van God kan egter met vertroue voortgaan en sy teologiese nadenke oor en navorsing van die Skrif voortsit. Die postmodernisme het immers óók die "metafisiese" ruimte weer erken (bv. in die New Age) en só die pad vir die verkondiging van die geloof weer oopgemaak. Dat die postmodemisme in sy konsekwente relativisme aanstoot neem aan die waarheidspretensie van die Christendom, is seker. Die kruis was egter nog altyd 'n skandalon - in die global village van die Hellenisme en in die meer omvattende global village van ons tyd.

\section{Bibliografie}

BRINTON, C. 1972. Enlightenment. (In The encyclopedia of philosophy, 2:519-525) 
BRUMFITT, J.H. 1972. The French Enlightenment. London : Macmillan.

CALVIN, J 1958 Tracts and treatises on the reformation of the church. Vol. 1 Transl. by H Beveridge Historical notes and introduction by T.F. Torrance Grand Rapids : Eerdmans.

CASSIRER, E. 1955. The philosophy of the Enlightenment. Transl by F.C.A. Koelln and J.P Pettegrove Boston : Beacon Press.

DOOYEWEERD, H 1949. Reformatie en scholastiek in de wijsbegeerte. Franeker : Wever

ESSER, H-H. 1997. Der Eigentumsbegriff Calvins angesichts der Einfuhrung der neuen Geldwirtschaft. (In Neuser, W.H. \& Armstrong B. eds. Calvinus sincerioris religionis vindex. Kirksville, Mis. : Sixteenth Century Joumal Publishers. p. 139-161.)

GAY, P. 1966. Introduction. (In Lanson, G. Voltaire New York : John Wiley \& Sons. p 111.)

GAY, P. 1967. The Enlightenment: An interpretation. The rise of modern paganism. New York : Knopf.

HEYNS, J.A. 1974. Die mens. Bloemfontein Sacum.

JENCKS, C. 1996. What is Post-Modernism? London : Academy Editions.

JOHNSON, P. 1988. Intellectuals. London : Weidenfeld and Nicolson.

KLAPWIJK, J. 1976. Dialektiek der Verlichting. Assen : Van Gorcum.

LANSON, G. 1966. Voltaire. English transl. by R.A. Wagoner. New York : John Wiley \& Sons.

LEE, H.B. 1992. Historical criticism of the Bible. Potchefstroom : PU for CHE. (Th.D. thesis) MEIJER, W.L. 1976. Kunst en revolutie. Goes : Oosterbaan \& Le Cointre.

MOORE, T.M. 1984. Some observations concerning the educational philosophy of John Calvin. The Westminster Theological Journal, 46(1):140-155.

PARKER, T.H.L. 1977. John Calvin. Berkhamsted : Lion Publishing.

PIEPMEIER, R. 1979. Aufklarung I. (In TRE, 4:575-594.)

POPMA, S.J. 1956. Aufklarung. (In Christelijke Encyclopedie, 1:373-375.)

ROHRMOSER, G. 1970. Das Elend der kritischen Theorie. Freiburg : Rombach

ROHRMOSER, G. 1976. De problematiek van de rede in het perspektief van het neomarxisme van de Frankfurter Schule. (In Klapwijk, J., Griffioen, S., Groenewoud, G. reds. Vrede met de rede? Assen : Van Gorcum. p. 87-96.)

ROLSTON, III, H. 1987. Science and religion. Philadelphia : Temple University Press

ROOKMAAKER, H R. 1970. Modern art and the death of a culture. London : Inter-Varsity.

ROSE, M.A. 1992. The post-modern and the post-industrial. A critical analysis Repr. Cambridge : Cambridge University Press.

SBOROS, M. 1998. Calling angel power. The Star: 13, March 27.

SCHALK, F. 1971. Aufklarung. (In Historisches Worterbuch der Philosophie, 1:619-634.)

SCHMIDT, M. 1979. Aufklärung II. (In TRE, 4:594-601.)

SCHOLL, H. 1997. Von der Reformation zur Revolution. Die beiden Genfer J Calvin und J.J. Rousseau vor der Frage nach sozialer Gerechtigkeit. (In Van 't Spijker, W, Selderhuis, J.H \& Neuser, W.H reds Calvin's Books. Festschrif for Peter de Klerk. Heerenveen : Groen p 235-256)

SCHULZE, L.F. 1985. Calvin and 'social ethics'. Pretoria : Kital.

TIPLER, F.J 1995 The physics of immortality 2nd ed. London : Macmillan.

TRE kyk Theologische Realencyclopädie.

VAN DER WALT, J.L. 1984. The school that Calvin established in 1559. (In Van der Walt, B J. ed. Our Reformational tradition. Potchefstroom : PU for CHE. p. 300-338.)

VOLTAIRE, 1986. Lettres philosophiques. Preface de Frédéric Deloffre. Paris : Gallimard. (Collection Folio, nr 1703.)

WENDEL, F. 1971. Calvin et l'humanisme. Publié par R. Peter. Paris : Presses Universitaires WENTSEL, B 1981. Het Woord, de Zoon en de Dienst. Dogmatiek, deel I. Kampen : Kok.

Koers 63(4) 1998:279.293 